\title{
地震動評価指標としてPSI值に着目した 防波堤の模型振動実験
}

\author{
大矢 陽介 1 - 小濱 英司 2 - 野津 厚 3 - 菅野 高弘 4 \\ 1正会員 独立行政法人港湾空港技術研究所（†239-0826 神奈川県横須賀市長瀬3-1-1） \\ E-mail:ooya-y@pari.go.jp \\ 2正会員 独立行政法人港湾空港技術研究所（†239-0826 神奈川県横須賀市長瀬3-1-1） \\ E-mail:kohama-e83ab@pari.go.jp \\ 3正会員 独立行政法人港湾空港技術研究所（ \\ E-mail:nozu@pari.go.jp \\ ${ }^{4}$ 正会員 独立行政法人港湾空港技術研究所（广239-0826 神奈川県横須賀市長瀬3-1-1） \\ E-mail:sugano@pari.go.jp
}

防波堤基礎の置換砂層が地震時に液状化すると防波堤は沈下し，後続の津波に対して必要な天端高を確 保できない可能性がある。このような沈下被害があった兵庫県南部地震の地震動と比較して, 近年のシナ リ才地震動は継続時間が長く, 地震規模の指標に使われるPSI值が大きいものが少なくない. 本研究では, このような長継続時間地震動に対する防波堤の沈下量を予測する目的で, 兵庫県南部地震の観測波形と南 海トラフの想定地震動を用いた1g場大型模型振動実験を実施した。振動実験の結果, 置換砂層における過 剰間隙水圧の上昇過程や防波堤の沈下速度には地震動の波形の特徵が現れた. また, 入力地震動のPSI值 が大きくなると沈下量は大きくなり，巨大な地震動に対して防波堤が大きく沈下する可能性が示された.

Key Words : breakwater, shake table test, liquefaction, power spectrum intensity, Nankai Trough

\section{1. はじめに}

防波堤の而津波性能照査にあたっては，防波堤の天端 高と津波高との関係が重要である. 特に津波を発生させ ようとする規模が大きい地震の場合，基礎地盤の液状化 が発生すれば防波堤は大きく沈下し，津波防御に必要な 天端高を確保できない可能性がある，この時，津波は大 きく越流するため，マウンドの洗掘等の進行により防波 堤の安定性は大きく低下寸る可能性もある. このような 地震によって防波堤が沈下寸る被害は，1995年兵庫県南 部地震および2000年鳥取県西部地震に見られた．前者で は，軟弱地盤対策として実施された床堀・置換工法によ って置き換えられた良質の砂（まさ土）において過剩間 隙水圧が上昇し，神戸港の防波堤は2 $\mathrm{m}$ 以上沈下した ${ }^{112}$. 一方，後者では大きくても $70 \mathrm{~cm}$ 程度の沈下被害であり， 置換砂層の有無に関わらず沈下しだ)ことから，原因は 置換砂層に限定できず，メカニズムはよく分かっていな い.

表-1に示すように，兵庫県南部地震の際に，神戸港で は施設総延長 $10 \mathrm{~km}$ のちち多くの防波堤が $2 \mathrm{~m}$ 以上沈下し
た ${ }^{4}$ ．直下型地震動である兵庫県南部地震のように継続 時間が短く, 最大加速度が大きな地震動に対して, 防波 堤は数m沈下寸る被災事例がある. 一方では, 現在発生 が想定されている継続時間が長い海溝型地震動に対して, どの程度防波堤が沈下寸るかは被災事例がなく，良く分 かっていない，また，実務の耐震性能照查等で用いられ ているレベル 2 シナリオ地震は, 兵庫県南部地震より地 震の規模が大きく, 数值解析では地震動の大きさに比例 して防波堤の被害も大きくなることが多い，このような 解析結果に対して被害の実例が無いため, 解析結果を受 け入れるほかない。

本研究は, 兵庫県南部地震の観測波と, これよりも地 震規模の指標である速度のPSI值が大きく, 継続時間が 長いシナリオ地震動を用いた1g場大型模型振動実験を実 施し，長継続時間地震動に対する防波堤の沈下挙動につ いて検討した。

\section{2. 実験内容 \\ (1) 入力地震動}


表-1＼cjkstart神戸港防波堤の被害（文献4)を修正）

\begin{tabular}{|c|c|c|c|c|c|}
\hline 施設名 & $\begin{array}{c}\text { 施設延長 } \\
\text { (m) }\end{array}$ & $\begin{array}{c}\text { 設計水深 } \\
\text { (m) }\end{array}$ & $\begin{array}{c}\text { 置換砂沈下率 } \\
\text { (\%) }\end{array}$ & $\begin{array}{c}\text { 法線変位量 } \\
\text { (最大值) } \\
\text { (cm) }\end{array}$ & $\begin{array}{c}\text { 天端沈下量 } \\
\text { (最大值) } \\
\text { (cm) }\end{array}$ \\
\hline 第1防波堤 & 1,220 & -6.0 & - & 30 & 143 \\
\hline 第 1 南防波堤 & 300 & -10.0 & 8.0 & 20 & 160 \\
\hline 和田岬防波堤 & 252 & -1.8 & - & 10 & 130 \\
\hline 第 2 防波堤 & 109 & -4.9 & 28.5 & 50 & 157 \\
\hline 第 3 防波堤（西） & 128 & -4.9 & 44.6 & 20 & 270 \\
\hline 第 3 防波堤（東） & 112 & -4.9 & 42.9 & 30 & 260 \\
\hline 第4防波堤 & 617 & -9.1 & 30.9 & 62 & 170 \\
\hline 第 5 防波堤 & 1,276 & -8.0 & 14.4 & 43 & 210 \\
\hline 第 6 防波堤 & 1,052 & -10.0 & 11.1 & 0 & 166 \\
\hline 第 6 南防波堤 & 828 & -12.0 & 10.5 & 43 & 241 \\
\hline 第 7 防波堤 & 4180 & -10.0 & 10.3 & 33 & 252 \\
\hline
\end{tabular}

実験は兵庫県南部地震の際のポートアイランドの鉛直 アレーサイトの記録5) (以後，PI波とする）と南海卜ラ フの地震（Mw9.0）を想定した地震動（以後，シナリオ 波とする）を用いた．後者は，SPGAモデルを用い南海 トラフの地震に対する強震動評価した地震動のうち，地 震基盤における速度のPSI值を近似的に計算し，50\%非 超過となる順位付けになった地震動)である。なお，PSI 值は速度波形の二乗積分值の平方根として定義される量 で，港湾構造物の被害程度と良い相関を示ずことから， 地震動の強さを表す指標として用いられている6). 図-1 に工学基盤における 2 つ波形の比較を示す．注䣋には， 最大加速度とPSI值を示した．PI波と比べてシナリオ波 の方が最大加速度は小さいが，継続時間が長くPSI值が 大きいのが特徴である.

模型実験の対象断面は，兵庫県南部地震の際に最大

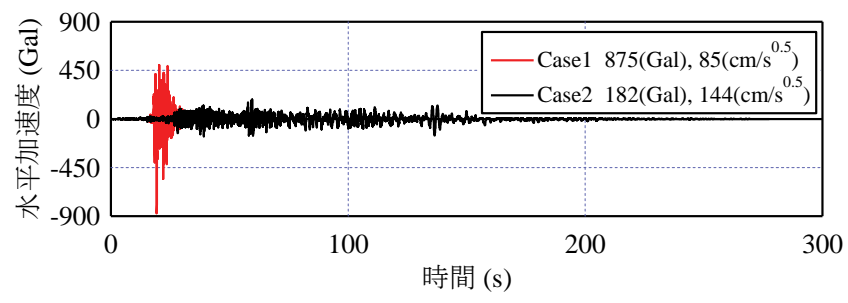

Case1 : PI 波, Case2 : シナリオ波

図-1＼cjkstart地震動の比較（工学基盤での2E波）

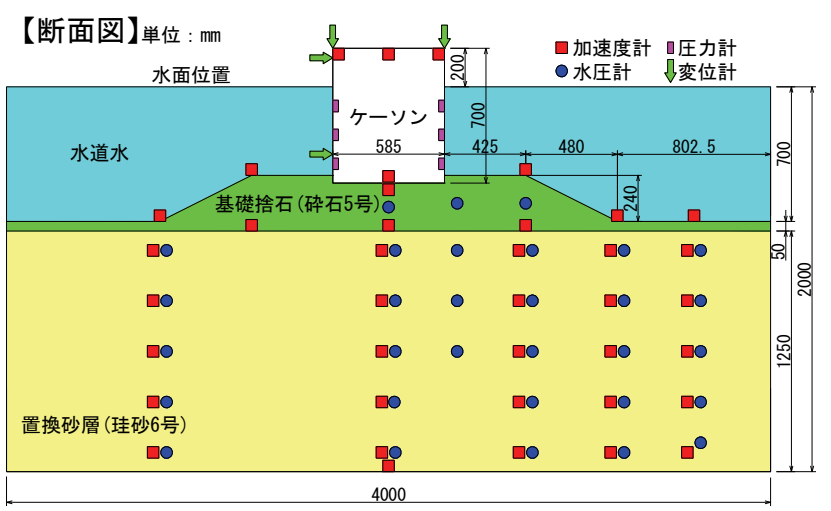

図-2＼cjkstart模型寸法と計測センサーの配置
2.6 m沈下した神戸港第 7 防波堤1) とした．基礎地盤の模 型は層厚25 mの置換砂層下端まで製作し，模型底面（振 動台位置) をポートアイランドのG.L.-32 m相当と設定し た. 振動台に設定する入力地震動は，PI波はその位置に おける鉛直アレ一記録を，シナリオ波は 1 次元有効応力 解析により求めたG.L.-32 m位置の加速度波形（E+F波） を用いた．ところで，ポートアイランドでは液状化が発 生し，波形にもその影響が現れたことから，対象とする G.L.32 mの地中においても，表層からの反射波の影響が ある. そのため, 1 次元有効応力解析には液状化を考慮 できる解析コードFLIP ${ }^{8)}$ と, 本研究で着目したPSI值の算 出に必要なポートアイランドの速度波形の再現性が高い 地盤モデルをを用いた.

先に実施したPI波を用いた実験（Case1）で計測した 振動台の最大加速度は，設定したG.L.-32 mのアレー記録 より大きく, PSI值も大きくなった. そのため，PI波と シナリオ波のPSI值の違いが明瞭になるよう，後で実施 したシナリオ波の実験（Case2）では，PSI值がCase1の2 倍になるよう加速度振幅を調整した。振動台で計測した 加速度波形は，図-4に他の計測結果と合わせて示した。

実験は，PI波（Case1-1）およびシナリ才波（Case2-1） の加振終了後に引き続き, 加速度振幅を変えたステップ 加振を行った. 実験ケース名において, Case1の後の番 号がステップ番号を表す. 2ステップ目以降のケースは, 基本ケース（Case1-1およびCase2-1）の後に実施したため, 地盤は変形し, 密度も変化しており, その変化を測るこ とができなかったため，実験結果は参考扱いとした。

\section{（2）模型製作}

図-2に模型寸法と計測センサーの配置図を示す。実験 は水中振動台に設置した長さ $4 \mathrm{~m}$ ，高さ $1.5 \mathrm{~m}$ ，奥行き 1.5 $\mathrm{m}$ の鋼製土槽を用いた. 土槽と対象断面の置換砂層厚さ を考慮して長さの縮尺比（実物スケール／模型スケー ル）を20とした．液状化を想定した置換砂層の厚さは， 実物25 mに対して模型は1.25 mである。相似則は，Iaiに 


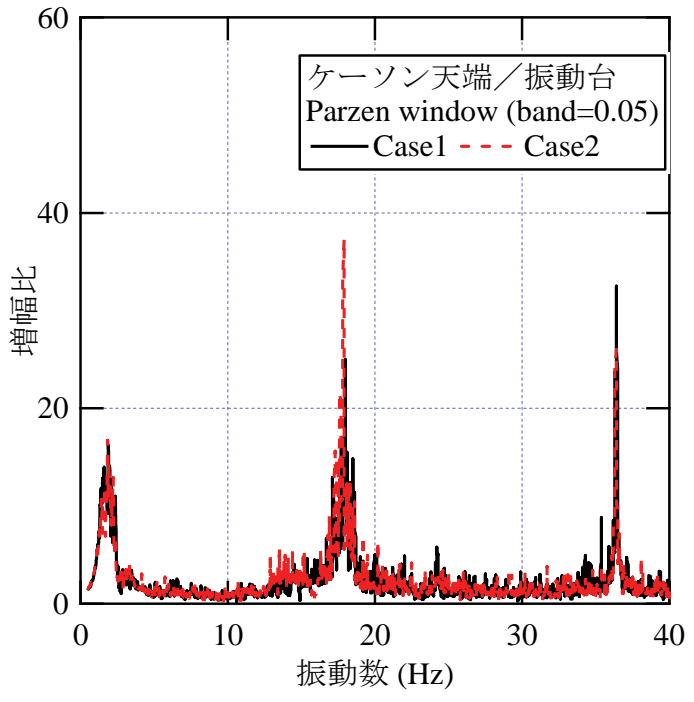

図-3 加振実験前の伝達関数

より提案された1g場における相似則 $\left.\right|^{10)}$ を啇用した。この 相似則は，二相系飽和材料（間隙水と土骨格）の力の釣 り合い式と連続の式に基づいて導き出されたものである. 以後, 特に断りがない場合は, 実験結果等の物理量は実 物スケールに換算した值とする.

置換砂層は飯豊珪砂6号 $\left(\rho_{\max }=1.706, \rho_{\min }=1.417 \mathrm{~g} / \mathrm{cm}^{3}\right)$ を水中落下法により相対密度 $50 \%$ を目標に製作した。 そ の後，捨石マウンドを気中落下法で製作後，表面を均し た後に鋼製のケーソンを設置した，なお，ケーソンは土 槽との摩擦を考慮して，奥行き方向に函に分けた.

図-3は，加振実験前にパルス波による加振を行い，模 型底面である振動台とケーソン天端に設置した加速度計 の波形について，伝達関数（ケーソン天端／振動台）を 求めたものである. 本実験では，2つの地震動について, それぞれ模型を製作した．複数の卓越振動数がおおよそ 一致していることから，2つの模型が等しい振動特性で あるといえる。

\section{3. 実験結果}

\section{(1) 時刻歴応答}

図-4にCase1-1（PI波）およびCase2-1（シナリオ波）で 計測した各種計測センサーの時刻歴図および対応するセ ンサー位置を示す．なお，過剩間隙水圧比は1次元地層 を仮定し，層厚と密度から求めた上載荷重で計測した過 剩間隙水圧を除した值である．また，沈下速度はケーソ ン天端の変位センサーで計測した沈下量を時間増分で除 し，計測ノイズの影響が無くなるようローパスフィルタ 一に通した.

時刻歴図には，説明しやすいよう時間軸方向に線を引
いた．赤線は過剩間隙水圧比が上昇し，ケーソンが沈下 し始める時刻である，青線（Case2-1のみ）は，さらに過 剩間隙水圧が上昇し，ケーソンの沈下速度が速くなった 時刻である. 緑線は, 加振が終了して加速度がほぼ 0 と なった時刻で，過剩間隙水圧が減少し始める時刻である.

まず，Case1-1とCase2-1で共通する結果を述べる．時刻 歴を示した2つの水圧計は，ケーソン中央直下とケーソ ン直下から離れたマウンド法尻直下の置換砂層中央に位 置する. ケーソン中央直下では過剩間隙水圧比は最大で も0.5程度，マウンド法尻直下では1以上となった．すな わち，ケーソン直下から離れたところでは液状化が発生 し，ケーソン直下では発生しなかった。このようにケー ソン直下で過剰間隙水圧比が1にならず液状化しない現 象は，ケーソン式護岸を対象とした模型実験でも確認さ れ ${ }^{11)}$ ，ケーソンの上載荷重と地盤の水平方向の拘束条件 が理由と考えられる.

マウンド法尻直下で過剩間隙水圧比が 0.5 まで上昇し た時（赤線），ケーソンは沈下し始めた。 その後，加速 度波形の主要動が終わっても，過剩間隙水圧比が高い状 態では，小さな加速度波形が入力されれば沈下量は増加 し続けた. 加振終了時（緑線）から過剩間隙水圧は消散 し始めたが，ケーソンの沈下量は増加せず，消散による 沈下量は小さかった.

次にCase1-1とCase2-1を比較すると，加速度波形の特徵 が各種計測結果に良く現れた。直下型地震動の特徵であ る振幅が大きな加速度波形が数回入力されるCase1-1では, マウンド法尻直下で過剩間隙水圧比は, 瞬時に1まで上 昇し液状化に至った。一方, 海溝型地震動の特徵である 振幅が小さく繰返し回数が多い加速度波形であるCase2-1 では，段階的に過剩間隙水圧が上昇した．Case2-1では加 振開始から50 秒まで100 Gal以下の加速度波形が続くが, 過剩間隙水圧はほとんど上昇せず，100 Galを超える波形 となった時（赤線），過剩間隙水圧は上昇した。あたか も100 Galが閾值であるように，これより大きな加速度に なる時（45，70，120 秒）過剩間隙水圧が段階的に上昇 し, 加振開始から70 秒経って置換砂層で液状化が発生 した.

過剩間隙水圧比の程度はCase1-1とCase2-1で違いが無く, 置換砂層の水圧上昇による岡性の軟化は，両ケースで同 程度と思われる. 沈下速度は入力加速度が大きいほど速 い傾向となり，Case1-1の方が沈下速度は速い，Case2-1は Case1-1よりも沈下速度は遅いが，地震動による繰返し載 荷を受け，沈下寸る継続時間が長いため，沈下量は Case1-1よりも大きくなった．また，Case2-1では，液状化 発生（青線）以降で, 沈下速度が速くなった.

\section{（2） 入力地震動と沈下量}

図-5に振動台で計測した最大加速度とケーソン天端の 


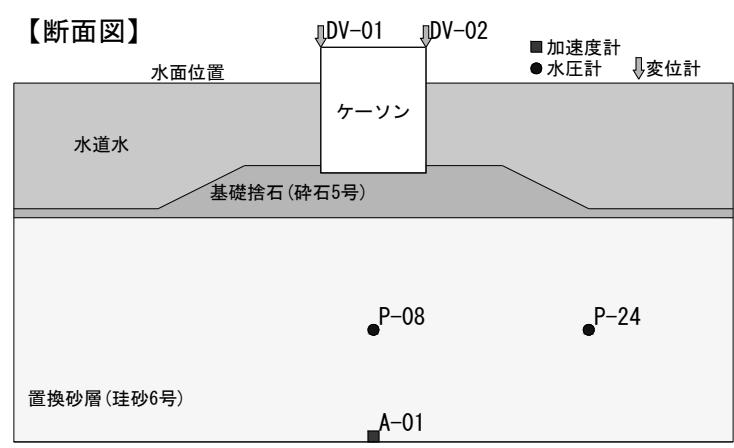

a) 出力した計測センサー位置
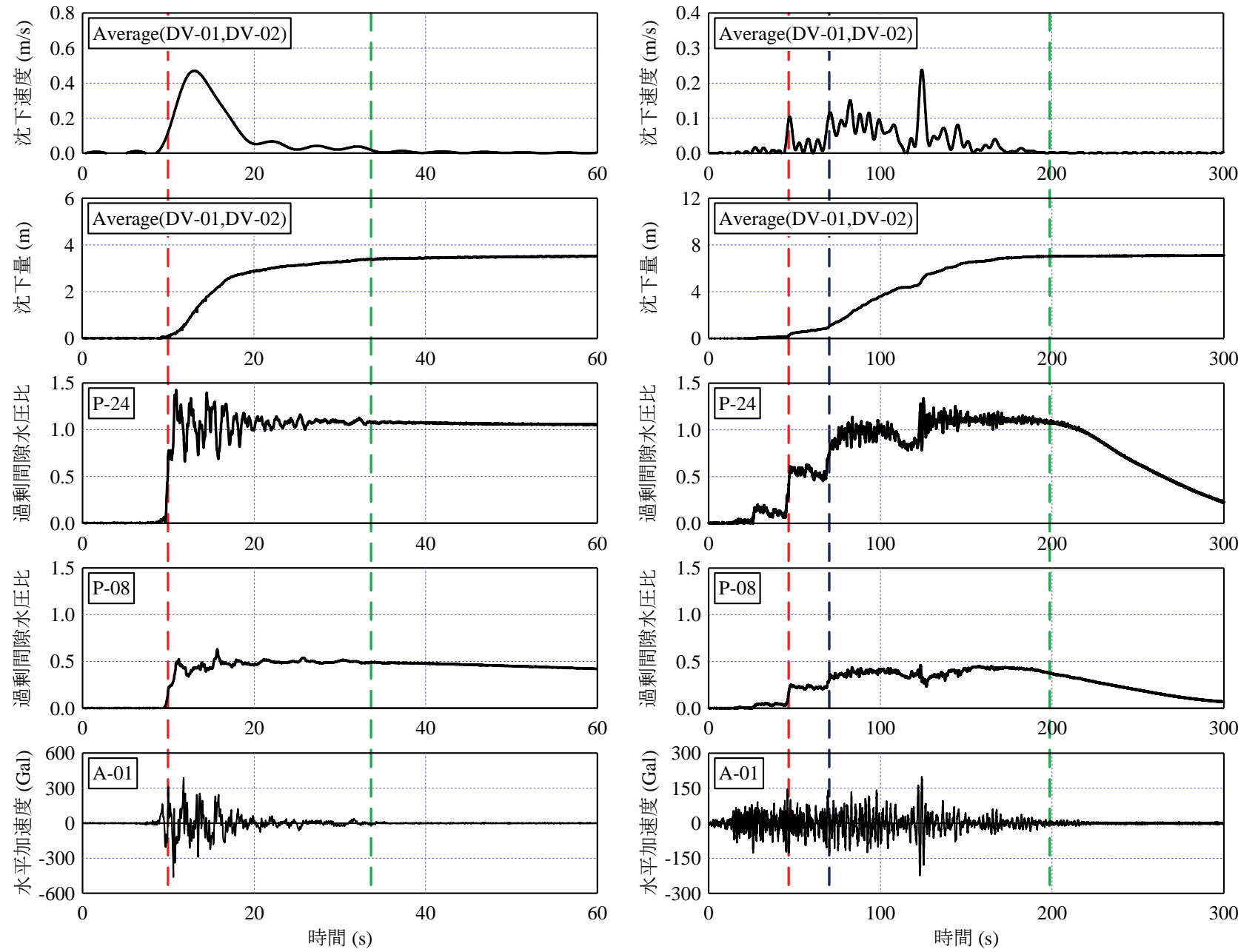

b) Case1-1

c) Case2-1

上から順に, 沈下速度, 沈下量, 過剩間隙水圧比, 水平加速度

図-4 出力したセンサ一位置と各種時刻歴図

沈下量の関係，図-6に振動台で計測した加速度波形から 求めたPSI值とケーソン天端の沈下量の関係を示す。困 中には，破線で囲んだ着目する基本ケース（Case1-1, Case2-1）の結果および神戸港第 7 防波堤の沈下量の実測 最大值に加え，ステップ加振の実験（Case1-2，1-3，1-4, 2-2，2-3）も参考值として示した. 沈下量は各ステップ において発生した沈下量であり，加速度とPSI值は振動 台における值で複合波（E+F波）相当である.

Case1-1は，兵庫県南部地震の際の観測波形を用いた再 現実験である. ケーソン天端の沈下量は3.6 mで，第 7

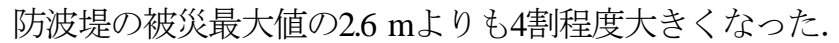
これは，前述のように振動台のPSI值が観測值よりも大 きくなったこと（Case1-1は99 cm/s $/ \mathrm{s}^{0.5}$ ，観測值は85 cm/s $\mathrm{s}^{0.5}$ ) に加えて，模型の置換砂層が実物と材料が異なることと 密度が小さかったことが原因と考えられる. Case2-1 $\left(\mathrm{PSI}\right.$ 值 $\left.=213 \mathrm{~cm} / \mathrm{s}^{0.5}\right)$ のケーソン天端の沈下量は7.1 mとな り, Case1-1の約2倍の沈下量となった.このように, 加 速度振幅が小さなシナリオ波の方が沈下量は大きく, 最 大加速度と沈下量は正の相関関係とはならなかった。一 方，Case1-1に対してCase2-1のPSI值と沈下量がともに約2 


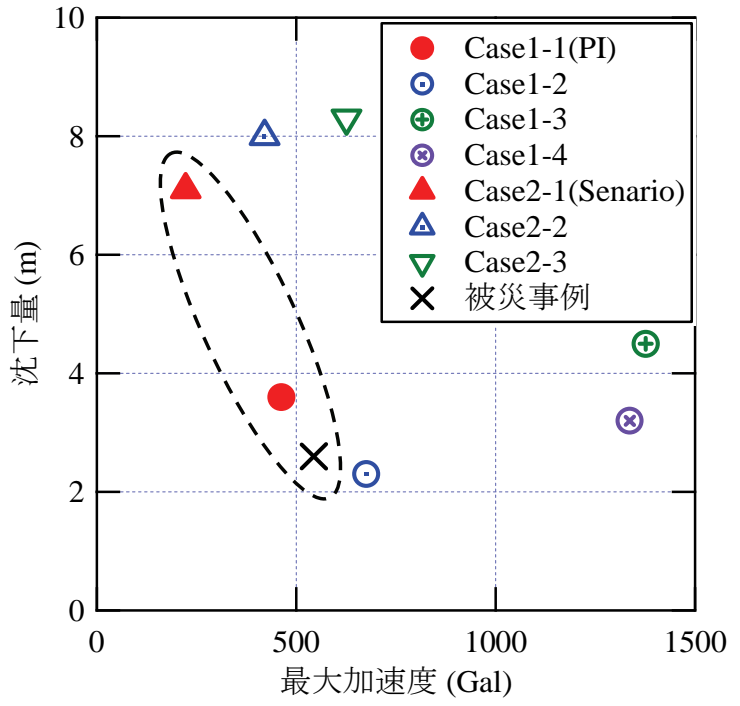

図-5＼cjkstart最大加速度と沈下量の関係

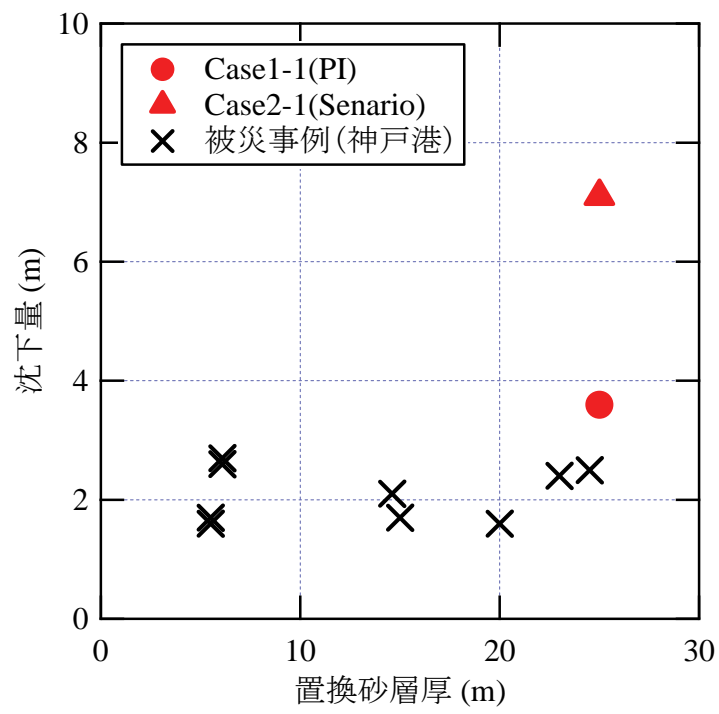

図-7 置換砂層厚と沈下量の関係

倍になったように，PSI值と沈下量は正の相関関係とな った. 継続時間や振動数の影響が考慮できない最大加速 度よりもPSI值の方が沈下量との相関が高く，沈下量に 対する地震動の強さを表す指標となりうる可能性が示さ れた.

2ステップ以降の実験は，連続する加振実験により地 盤が密になっているにも関わらず，PSI值が大きくなれ ば引き続き数mオーダーの沈下が発生する結果となった

図-7に置換砂層厚と沈下量の関係，図-8に置換砂層厚 と置換砂層沈下率の関係を示寸．図中には，第 7 防波堤 の被災量に加えて，表-1に示した神戸港の被災事例を示 した. 兵庫県南部地震の神戸港の被災事例では，置換砂 層厚が $6 \mathrm{~m}$ から $25 \mathrm{~m}$ と違いがあっても，層厚に関わらず2 $\mathrm{m}$ 前後防波堤は沈下した．それゆえ，置換砂層厚に対寸 る沈下量の比率を表す置換砂層沈下率は, 層厚が薄いと ころで50\%弱，層厚が厚くなると $10 \%$ 程度に収束する傾 向となった.

被災事例と同等の地震波（PI波）を用いたCase1-1の結 果は，これらの被災事例と近いところにプロットされた.

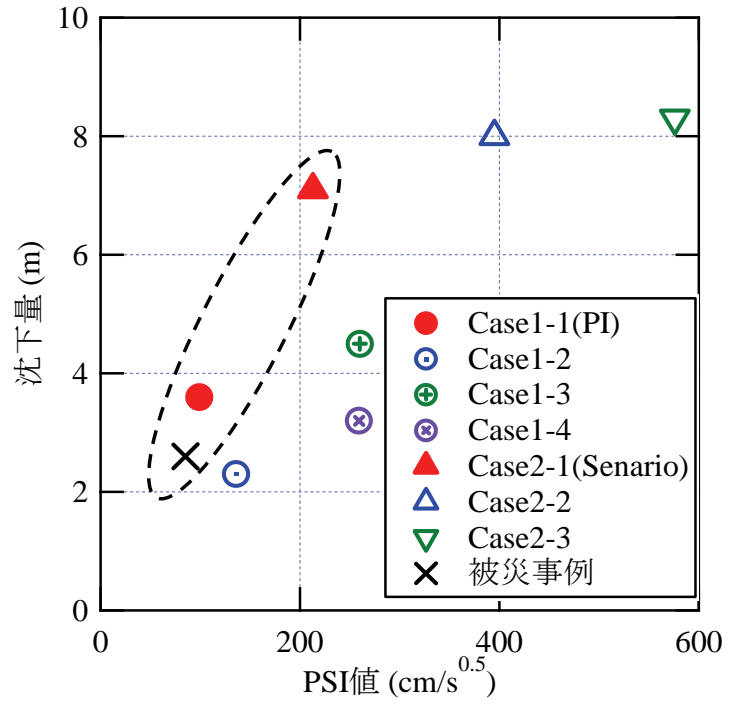

図-6 PSI 值と沈下量の関係

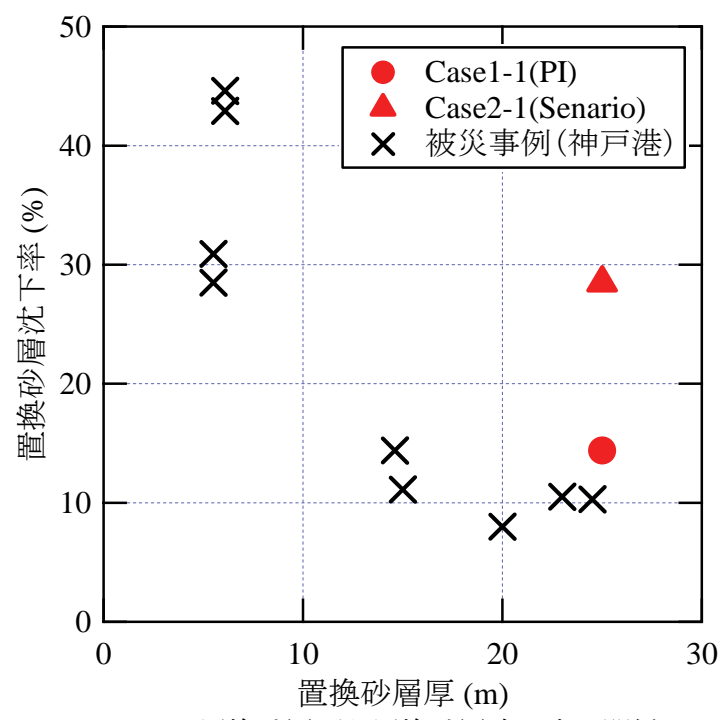

図-8 置換砂層厚と置換砂層沈下率の関係

一方，シナリオ波（Case2-1）の結果は，沈下量と置換砂 層沈下率が神戸港の被災事例より2倍程度大きいところ にプロットされ，PSI值が大きい地震動の影響が示され た.

\section{4. 結論}

長継続時間地震動では, 加速度振幅が大きくないため 突発的な液状化は発生しないが，時間とともに地盤がせ ん断変形することで徐々に過剩間隙水圧は高くなり，液 状化が発生した．ケーソンの沈下は，地盤の過剩間隙水 圧比が 0.5 程度に上昇してから発生し，過剩間隙水圧比 が1に至り液状化が発生すると急激に増加した。

置換砂層の厚さや密度, そして地震動の規模は, 本研 究で行った限られた条件であるが，発生が想定されてい る継続時間が長い巨大地震に対して，防波堤の基礎地盤 が液状化すれば，防波堤が大きく沈下する可能性を示し た. また, PSI值は最大加速度よりも沈下量に対する相 
関が高く，防波堤の被害を推定する際の地震動の強さを 表寸指標となりうる可能性が示唆されたものと考えられ る.

本研究では, PSI值がより大きな地震動を対象とした 実験を行っておらず, 研究の興味はPSI值がさらに大き くなったときの沈下量の最大值に行き着く. 盛土を対象 とした場合，基礎地盤が液状化した際の実被害は，沈下 量の最大值は堤体高の0.75倍より小さい12). また，エネ ルギー原理に基づく予測手法では, 盛土の最終沈下量は, 盛土の荷重（密度 $\times$ 堤体高）と盛土底面に働く液状化地 盤の浮力が釣り合う位置で決まる ${ }^{13)}$.このように，盛土 については，実被害に合わせて最大沈下量に関する研究 もある. 一方，防波堤の場合，ケーソンの密度（一般的 に21 kN/m³゙使われる ${ }^{14)}$ ) は液状化した地盤の密度より も大きいことから，ケーソンの荷重と液状化地盤の浮力 が釣り合うことは無いこと、また，実験結果のようにケ ーソン直下の置換砂層は，完全液状化しないこと．そし て，繰返しせん断が終了したところで沈下が終了寸るた め(図-4より) , 浮力と釣り合うというメカニズムとは 異なるメカニズムで沈下量が決まること．これらの理由 により, 基礎地盤が液状化した盛土の最大沈下量の議論 とは前提条件が異なり，より大きな地震動に対する防波 堤の最大沈下量の予測は難しい. 今後, 本研究で用いた PSI值より大きな地震動や置換砂層の厚さや密度が異な る断面を対象として, さらなる実験や数值解析による検 討が必要である.

\section{参考文献}

1) 稲富隆昌, 善功企, 外山進一, 上部達生, 井合進, 菅野高弘, 寺内潔, 横田弘, 藤本健幸, 田中祐人, 山崎浩之, 小泉哲也, 長尾毅, 野津厚, 宮田正史, 一井康二, 森田年一, 南兼一郎, 及川研, 松永康男, 石井正樹, 杉山盛行, 高崎伸彦, 小林延行, 岡部勝 彦 : 1995 年兵庫県南部地震による港湾施設等被害報 告，港湾技研資料，No.857， pp.1208-1223， 1997.
2) 菅野高弘，宮田正史，三藤正明，稲垣紘史，及川研， 飯塚栄寿: 平成 7 年兵庫県南部地震時の港湾 - 海岸 施設の挙動に関する研究, 海岸工学論文集, 第 43 巻, pp.1311-1315, 1996.

3) 井合進, 菅野高弘, 山㠃浩之, 長尾毅, 野津厚, 一 井康二, 森川嘉之, 小濱英司, 西守男雄, 佐藤陽子, 田中剛, 海老原健介, 大村武史, 大槙正紀 : 平成 1 2 年 ( 2000 年) 鳥取県西部地震による港湾施設 等の被害報告, 港湾空港技術研究所資料, No.1015, 126pp., 2001.

4) 第三港湾建設局, 神戸港湾震災復旧事務所 : 阪神 淡路大震災により被災した神戸港港湾施設の復旧設 計, 第 27 回管内工事施行技術研究資料, 174pp., 1996.

5) 震災予防協会: 強震動アレー観測, No.3, 1998.

6) 野津厚 : 南海トラフの地震（Mw9.0）を対象とした SPGA モデルによる強震動評価事例，土木学会第 32 回地震工学研究発表会講演論文集, 15pp., 2012.

7) 野津厚, 井合進 : 岸壁の即時被害推定に用いる地震 動指標に関する一考察, 第 28 回土木学会関東支部技 術研究発表会講演概要集, pp.18-19, 2001.

8) Iai, S., Matsunaga, Y. and Kameoka, T.: Strain space plasticity model for cyclic mobility, Soils and Foundations, Vol.32, No.2, pp.1-15, 1992.

9) 野津厚 : 非線形パラメタと有効応力解析を併用した 強震動評価手法, 土木学会地震工学論文集, Vol.29, pp.114-122, 2007.

10) Iai, S.: Similitude for Shaking Table Tests on SoilStructure-Fluid Model in 1g Gravitational Field, Report of P.H.R.I., Vol.27, No.3, pp.3-24, 1988.

11）大矢陽介, 小濱英司, 高橋英紀, 伊勢勉, 吉田誠 : 海底面の傾斜がケーソン式護岸の地震時応答に与え る影響に関する大型模型振動実験, 土木学会論文集 A1(構造 - 地震工学), Vol.68, No.4, pp.I_355-I_364, 2012.

12）国土交通省：レベル 2 地震動に対する河川堤防の耐 震点検マニュアル，24pp., 2012.

13）水谷崇亮：液状化に起因する盛土基礎の側方流動の 矢板による軽減, 東京大学学位論文, 218pp., 2000 .

14）沿岸開発技術研究センター, 運輸省港湾局監修: 埋立地 の液状化対策ハンドブック（改訂版），p.97，1997.

\title{
A SHAKE TABLE TEST OF BREAKWATER WHICH PAID ITS ATTENTION TO POWER SPECTRUM INTENSITY AS AN EARTHQUAKE MOTION EVALUATION INDEX
}

\author{
Yousuke OHYA, Eiji KOHAMA, Atsushi NOZU and Takahiro SUGANO
}

If a replaced sand base of a breakwater liquefies during an earthquake, the breakwater should subside and may be unabele to keep the level of breakwater to defend the coast region from Tsunami. As compared with the 1995 Hyogoken-nanbu earthquake with such subsidence damages, scenario earthquakes in recent years has long continuation time, and there are many scenario earthquakes which have a larger power spectrum intensity(PSI) used for the index of earthquake motion scale. In this study, shake table tests of a large model in $1 \mathrm{~g}$ gravitational field were conducted in order to predict the amount of subsidence of the breakwater to such a long continuation earthquake motion. There was significant correlation between the PSI and the amount of subsidence; the larger PSI an input earthquake motion had, the larger subsidence was. 